\title{
man \\ A Qualitative Assessment of the Specific Woody Biomass of Fruit Trees
}

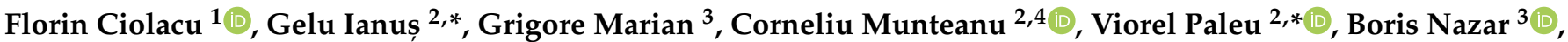 \\ Bogdan Istrate ${ }^{2} \mathbb{D}$, Andrei Gudîma ${ }^{3}$ and Nicolae Daraduda ${ }^{3, *(D)}$
}

Citation: Ciolacu, F.; Ianuș, G.; Marian, G.; Munteanu, C.; Paleu, V.; Nazar, B.; Istrate, B.; Gudîma, A.; Daraduda, N. A Qualitative Assessment of the Specific Woody Biomass of Fruit Trees. Forests 2022, 13, 405. https://doi.org/10.3390/ f13030405

Academic Editor: Zeki Candan

Received: 11 February 2022

Accepted: 28 February 2022

Published: 2 March 2022

Publisher's Note: MDPI stays neutral with regard to jurisdictional claims in published maps and institutional affiliations.

Copyright: (c) 2022 by the authors. Licensee MDPI, Basel, Switzerland. This article is an open access article distributed under the terms and conditions of the Creative Commons Attribution (CC BY) license (https:// creativecommons.org/licenses/by/ $4.0 /)$.
1 Natural and Synthetic Polymers Department, Faculty of Chemical Engineering and Environmental Protection, Gheorghe Asachi Technical University of Iași, 73 D. Mangeron Blvd., 700050 Iasi, Romania; florin.ciolacu@academic.tuiasi.ro

2 Mechanical Engineering, Mechatronics and Robotics Department, Faculty of Mechanical Engineering, Gheorghe Asachi Technical University of Iași, 61-63 D. Mangeron Blvd., 700050 Iasi, Romania; corneliu.munteanu@academic.tuiasi.ro (C.M.); bogdan.istrate@academic.tuiasi.ro (B.I.)

3 Solid Biofuels Laboratory, State Agrarian University of Moldova, 44 Mircesti Str., MD 2049 Chișinău, Moldova; marian@uasm.md (G.M.); b.nazar@uasm.md (B.N.); andreigudima@rambler.ru (A.G.)

4 Technical Sciences Academy of Romania, 26 Dacia Blvd., 030167 Bucharest, Romania

* Correspondence: gelu.ianus@academic.tuiasi.ro (G.I.); viorel.paleu@academic.tuiasi.ro (V.P.); n.daraduda@uasm.md (N.D.)

\begin{abstract}
In the current context of environmental requirements, solid renewable biomass is becoming one of the main viable energy sources that can replace fossil fuels. This paper focuses on evaluating the morphological structure and properties of three fruit trees that are widely grown on the territory of Moldova, both on the left and the right banks of the Prut River: the apricot, the peach, and the plum. The wood biomass was characterized by scanning electron microscopy (SEM Quanta 200 3D), X-ray analysis (Xpert PRO MPD), and FT-IR analysis. A chemical analysis including the determination of extractive substances, lignin content, and the detection of hemicelluloses content was carried out for all wood samples. In addition, the net calorific value was determined by measuring the calorific value at constant volume, in compliance with the requirements of the EN ISO 18125:2017 standard. According to the obtained results, in terms of maximum calorific output and lignin and minimum ash content, plum appeared to be the best solid biomass resource. However, the other two trees also showed promising results for becoming important sources of wood biomass for pellet production.
\end{abstract}

Keywords: vegetal biomass; apricot; peach; plum; morphological analysis; SEM analysis; XRD analysis; FTIR; calorimetric analysis

\section{Introduction}

Nowadays, in EU countries the necessity of industrial heat is still mainly obtained from fossil fuels. The demand for renewable energy sources is increasing. The main renewable energy source for industrial heating is solid biomass. A recent study by Malico et al. [1] analyzed the available solid biomass feedstock. The paper emphasized that there is now a balance in Europe between biomass production and consumption, but warned about the necessity of monitoring and sustaining biomass production.

Considering the shear of solid biomass in the Gross Energy Final Consumption (GEFC) index, Romania was at the top of the index in 2018, with $13.9 \%$, immediately after Baltic and Scandinavian countries, Croatia, and Austria $[2,3]$.

Solid biomass for energy purposes can be produced from [1]:

(a) Residual organic matter resulting from forests and uncultivated lands;

(b) Energy crops;

(c) Wastes and residues produced in industrial, agricultural and forestry activities;

(d) Municipal wastes. 
The biomass feedstock is composed of:

(a) Raw biomass (wood chips, bark or nut shells);

(b) Upgraded solid biofuels (e.g., pellets, charcoal or torrefied biomass) [4].

Upgraded biomass is more efficient than raw biomass, being subjected to thermal treatments to upgrade its efficiency in supplied energy and density. The previously densified upgraded biomass is easier and cheaper to transport and store. The most employed technological processes in obtaining upgraded solid biomass are [5]: pelletization, pyrolysis, and torrefaction. Moreover, solid biomass can be converted into liquid or gaseous biofuels.

An evaluation of wood and crop residues for wheat straw and canola straw, according to availability in the Czech Republic, lignocellulosic raw material, moisture, and fibre properties, was realized by Procházka et al. [6], and the most suitable candidate for wood-based composites was identified as soft wood. Regarding the evaluation of the fruit trees as solid biomass for briquettes production, there are studies on guava wood that present negative results, as the measured Sulphur content $(0.063 \%)$ and ash content $(3.74 \%)$ exceeded the allowed limits for graded wood briquettes [7]. Kamperidou et al. [8] determined the calorific value and ash content of woody material and the bark of Mediterranean species and established the percentage of bark of each species in relation to the corresponding diameter. In order to approach the ratio that meets the requirements of the standards in terms of ash percentage and calorific value, the ratio of all studied species in the mixture was also investigated. Ngangyo-Heya et al. [9] reported results on the calorific value and chemical composition of five semi-arid Mexican tree species, underlining the content of lignin in trunks, branches and twigs, and proving that the calorific value directly depends on lignin content. A formal relationship between the type of process that generates residues, their properties, and the quality of the wood pellets can help optimize the pellet production process [10]. Reis Portilho et al. [11] investigated the potential of briquette produced by torrefying agroforestry biomass to generate energy, reporting that torrefaction and briquetting increased the energy potential of the biomasses. Gruber et al. [12] established the calorific value and ash content of extracted birch bark, concluding that the higher the ash content of extracted birch bark, the lower the energy content.

From an engineering viewpoint, experimental research on solid biomass requests the determination of their physical properties, for example by particle density, bulk density, and oven dry tests, particle size distribution, large-scale annular shear, linear wall friction, angle of repose, and attrition tests [13].

Mediavilla et al. [4] emphasized the potential of shrub lands as a source of raw material for a bioeconomy-based future, determined the combustion performances of shrub biomass by combustion tests on shrub pellets, and predicted the fuel indices related to emissions, deposit build-up, and ash melting. Shrub biomass was collected both manually and mechanically, and the main properties and chemical composition were established. The X-ray diffraction technique was employed for the analysis of crystalline phases in the collected ash after different combustion tests. From the obtained constituents, the melting points were predicted. The study included the Mediterranean area and species such as broom, rockrose, and gorse.

SEM and TEM analysis of char was performed by Trubetskaya et al. [14], helping in understanding its structural and chemical properties. Soot samples were studied on the transmission electron microscope (TEM). The elemental analysis was also performed. Acetanilide was used as a reference standard. The ash content was determined using a standard ash test at $550{ }^{\circ} \mathrm{C}$, according to the procedure described in DIN EN 14775. Trubetskaya et al. [14] and Wang et al. [15] utilized optical microscopy (OM), C CP/MAS NMR, FTIR, SEM and XRD analyses to assess the cellulose content in pine wood, observing a dense and homogeneous structure. SEM micrographs are extensively used to study: wood cellulose fibers [16]; biomass pinewood and beechwood chars [14]; different cellulose particle types of wood fiber including MCC, microfibrillated cellulose, and tunicate cellulose nanocrystals [17,18]; potato starch phosphate and cellulose phosphate particles [18,19]; cross-section images of natural wood (NW) and delignified wood (DW) [20]; the tensile 
fracture surface of natural wood and densified wood samples [21]; cellulose, hemicelluloses, and lignin chars from olive stones fractionated at $180 \circ \mathrm{C}$ [22]; lignin fusion with cellulose fibers and wood cells (tracheids) [23]; and micrographs of micro- and nano-particles from beech acidolysis lignin [24,25].

For phase analysis of the elements composing the wood biomass, X-ray diffraction (XRD) of microstructure constituents of wood subjected to acid and alkali treatments were presented by Xu et al. [26]. Moreover, the XRD method was employed to analyze crystalline phases in the bottom ash collected after the different combustion test [4], cellulose-rich extract pattern detection [15], $\mathrm{TiO} 2$-cellulose nanocomposites and $\mathrm{TiO} 2$ (anatase) [16], individual fibers related to the production of papers and fiberboards [26], and other forms of solid biomass [25]. The EDS spectrum of $\mathrm{TiO} 2$-cellulose nanocomposites was presented by [16]. Fourier-transform infrared spectroscopy (FT-IR) is a very useful technique for analyzing the chemical composition of wood $[15,25]$ for cellulose modification degree [16], but also for the determination of the gaseous composition of exhaust gases from combustion tests [4].

After a survey of the existing literature, it was observed that SEM images of biomass fibers and of resulting combustion products (ash, soot, and char) are of interest for scientific research regarding solid biomass $[27,28]$. These images can be correlated with results regarding combustion performances, biomass density, particle size distribution, etc. Moreover, XRD, and FT-IR analysis are useful for the establishment of the chemical composition of both solid biomass and residual combustion products, the results providing information about the melting points of the biomass products. All the results must be correlated with the actual standards imposed for biomass combustion performances and environmental regulations.

The estimated annual energy potential of the residues resulting from the pruning of apricot, peach, and plum trees on the territory of the Republic of Moldova is shown in Table 1 [29-31].

Table 1. The reflection positions of crystal planes and amorphous cellulose forms for the studied wood samples.

\begin{tabular}{ccccc}
\hline \multirow{2}{*}{ Crop Name } & \multicolumn{2}{c}{$\mathbf{P T R}_{\mathbf{M}=\mathbf{1 0} \%}(\mathbf{G J} / \mathbf{h a})$} & \multicolumn{2}{c}{$\mathbf{P S I}_{\mathbf{M}=\mathbf{1 0} \%}$ (GJ/an) } \\
\cline { 2 - 5 } & $\mathbf{M a x}$ & $\mathbf{M i n}$ & $\mathbf{M a x}$ & $\mathbf{M i n}$ \\
\hline Apricot trees & 23.1 & 15.7 & 16.6 & 11.3 \\
\hline Peach trees & 22.1 & 16.2 & 15.9 & 11.7 \\
\hline Plum trees & 22.1 & 16.2 & 15.9 & 11.7 \\
\hline
\end{tabular}

Note: PTR $_{\mathrm{M}=10 \%}$ (in GJ/ha)—theoretical residual energy potential calculated for biomass with a moisture content of $10 \%$; $\mathrm{PSI}_{\mathrm{M}=10 \%}$ (in GJ/year) — the sustainable energy potential of the residues calculated for biomass with a moisture content of $10 \%$.

Considering the above-mentioned biomass resources, this study aims to conduct a morphological, structural, and chemical evaluation of wood biomass from both banks of the Prut River (the border between the Republic of Moldova and Romania, located in Eastern Europe), focusing on the three specified fruit trees: apricots, peaches, and plums. To our knowledge, no other studies are available in the literature on this subject.

\section{Materials and Methods}

\subsection{Materials}

Energy production from agricultural biomass is the most popular option in rural areas of Moldova and Romania. Results from the literature show that agricultural tree residues provide densified solid biofuels with properties complying with EN Plus 3 requirements [29-31]. Samples of agricultural residues generated as a result of the pruning of apricot, peach and plum trees grown on both sides of the Prut River in the Republic of Moldova and Romania were used as the object of this research. 
The samples were collected after the dry pruning in March and April 2020. Coarse shredding was carried out directly in the field with the inclined loading shredder "Morena 1", made in the Czech Republic. Moisture conditioning was carried out by the natural conversion method in the dryer of the Solid Biofuels Laboratory, UASM, up to the moisture content $\mathrm{M}=8 \pm 2 \%$.

Figure 1 shows the biomass samples before conditioning and after shredding.
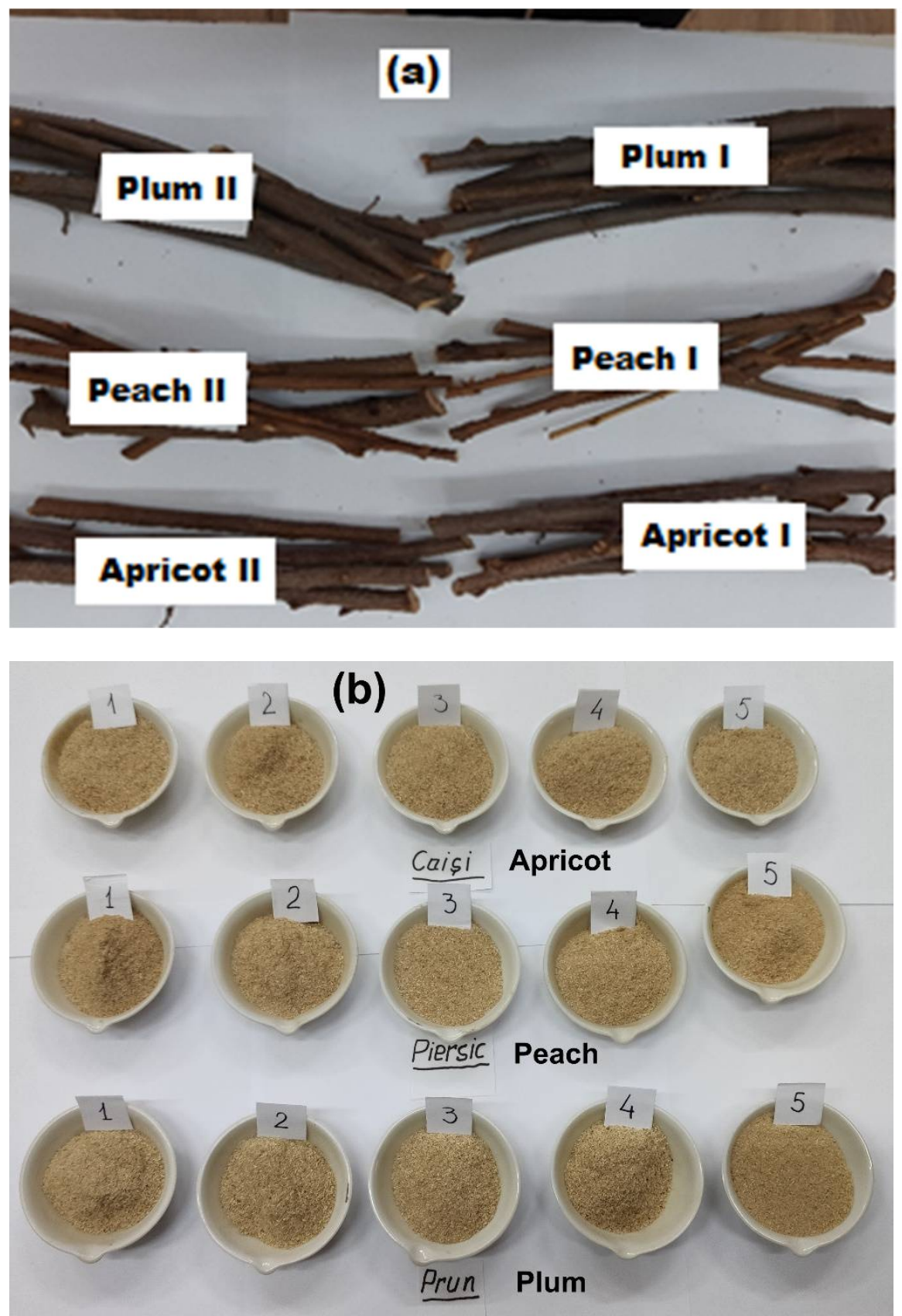

Figure 1. Biomass samples used in this research: (a) pruning residues; (b) shredded biomass samples.

Depending on the thickness of the specimen cut from the tree, the proportion of bark in the wood may vary [8]. Bark content depends heavily on the part of the tree to be investigated [32]. The results of weighing after removing the bark from our three similar analyzed samples are highlighted in Table 2. The data obtained from five similar measurements, in terms of the percentage of bark-wood, were consistent with the existing literature in terms of branch and twig diameter [33-35]. 
Table 2. Bark content of samples.

\begin{tabular}{ccccccc}
\hline Samples & Total Mass, $\mathbf{g}$ & Mass Without Bark, $\mathbf{g}$ & Bark Content, $\%$ & Std. Err., $\%$ & Mean Diameter, mm \\
\hline Apricot & 0.3205 & 0.2739 & 14.54 & \pm 2.52 & 9.8 \\
\hline Peach & 0.2585 & 0.2346 & 9.25 & \pm 2.35 & 10.1 \\
\hline Plum & 0.6155 & 0.5243 & 14.82 & \pm 2.64 & 11.5 \\
\hline
\end{tabular}

For technical or economic reasons, no solid biofuel producer separates the bark from the wood base in the case of thin branches and twig pruning residues [34]. Our study focused on the analysis of biomass used under real production conditions, i.e., without structural separation. These data are of interest to producers of densified solid biofuels.

\subsection{Methods}

The surface morphology of the wood was investigated by scanning electron microscopy (SEM FEI Quanta 200 3d-dual beam, equipped with energy dispersive X-ray spectroscopy analysis unit-Xflash Bruker, USA). X-ray diffractions (XRD) were performed using a XPERT PRO MPD 3060 facility from Panalytical (Netherlands), with a Cu X-ray tube $(\mathrm{K} \alpha=0.154051 \mathrm{~nm}), 2$ Theta: $10^{\circ}-40^{\circ}$, step size: $0.13^{\circ}$, time/step: $51 \mathrm{~s}$, and a scan speed of $0.065651^{\circ}$ /s. FT-IR spectra were recorded on solid samples in KBR pellets by means of a FT-IR Bruker spectrometer with a resolution of $4 \mathrm{~cm}^{-1}$.

Chemical analysis of the conditioned samples was based on the following procedure:

1. Moisture determination by the drying method using an analytical moisture balance (TAPPI T $264 \mathrm{~cm}-07$ - preparation of wood for chemical analysis);

2. Determination of extractive substances (S.E. alc-toluene, \%) using ethanol-toluene (1:2) solution by Soxhlet extraction (TAPPI T204 cm-17 Solvent extractives of wood and pulp, ASTM D1107-21—standard test method for ethanol-toluene solubility of wood);

3. Determination of lignin content ( $\mathrm{L}, \%)$ by Klason method (ISO/DIS 21,436 Pulpsdetermination of lignin content-acid hydrolysis method);

4. Detection of hemicellulose content $(\mathrm{HC}, \%)$ by the fast one-step acid hydrolysis method (4 wt \% sulfuric acid hydrolysis at $121^{\circ} \mathrm{C}$ for $1 \mathrm{~h}$ ) [36];

5. Recording of FTIR spectra using a BRUKER FTIR spectrophotometer and the $\mathrm{KBr}$ pellet technique. Although attenuated total reflection (ATR) is a method that allows the direct measurement of powder samples, FTIR-ATR is rather a method for obtaining infrared information related to the surface of the powder sample. FTIR-ATR spectroscopy has a penetration depth of around $200 \mathrm{~nm}$, depending on ATR crystal material. For our powder samples, with particle sizes much larger than $200 \mathrm{~nm}$ and an inhomogeneity specific to the plant material, FTIR transmission is recommended. Furthermore, the KBr pellet method gives greater resolution than the ATR. The ATR method gives a lot of interference below 600 wavenumbers, so is only practical to measure down to $650 \mathrm{~cm}^{-1}$. With the $\mathrm{KBr}$ pellet method on the other hand, one can go down to $450 \mathrm{~cm}^{-1}$.

Moisture content of biomass taken immediately after tree pruning operations was determined by weighing according to the SM EN ISO 18134 1-3: 2017 standards, which involve the removal of moisture from the test material. Five samples for each biomass type were analyzed, taken according to the requirements of SM EN 18135:2017. The samples taken in the study were shredded using an SM 100 mill (made Germany) and passed through a sieve with a mesh size of $1 \mathrm{~mm}$. Contact with the atmosphere was avoided along the way to exclude any loss of moisture from the samples.

The moisture content on a dry basis was calculated using the following formula:

$$
U_{d}=\frac{m-m_{0}}{m_{0}} 100 \%
$$


where $m$ is the mass of the biomass sample in the moist state in grams, and $m_{0}$ is the mass of the same biomass sample estimated after drying in the oven to a constant value, in grams.

The moisture content on a wet basis was determined with the relationship:

$$
M_{a r}=\frac{m-m_{0}}{m} 100 \%
$$

The first formula calculates the standard water content in wood, which is the percentage ratio of the water mass in the wood and the mass of the wood in the oven-dry state. The second is the technical water content in wood, which is the percentage ratio of water mass in wood and wood mass in some water content.

The net calorific value was determined by measuring the calorific value at a constant volume using the German-manufactured IKA C6000 isoperibolic calorimeter equipment, in accordance with the requirements of SM EN ISO 18125:2017.

The net calorific value was calculated for biomass with moisture 0 and for moisture $10 \%$ using the following relations:

$$
\begin{gathered}
\mathrm{q}_{\mathrm{p}, \text { net, } \mathrm{d}}=\mathrm{q}_{\mathrm{v}, \mathrm{gr}, \mathrm{d}}-212.2 \cdot \mathrm{w}(\mathrm{H})_{\mathrm{d}}-0.8 \cdot\left[\mathrm{w}(\mathrm{O})_{\mathrm{d}}+\mathrm{w}(\mathrm{N})_{\mathrm{d}}\right] \\
\mathrm{q}_{\mathrm{p}, \mathrm{net}, \mathrm{M}}=\mathrm{q}_{\mathrm{v}, \mathrm{gr}, \mathrm{d}}-(1-0.01 \mathrm{M})-24.43 \mathrm{M}
\end{gathered}
$$

where:

$\mathrm{q}_{\mathrm{p}, \text { net,d }}$ is the net calorific value measured at constant pressure and determined for samples with humidity $0, \mathrm{~J} / \mathrm{g}$;

$\mathrm{q}_{\mathrm{p}, \text { net, } \mathrm{M}}$ is the net calorific value measured at constant pressure and determined for samples with humidity $0, \mathrm{~J} / \mathrm{g}$;

$\mathrm{q}_{(\mathrm{v}, \mathrm{gr}, \mathrm{d})}$ is the gross calorific value at constant volume, $\mathrm{J} / \mathrm{g}$;

$\mathrm{w}(\mathrm{H})_{\mathrm{d}}$ is the hydrogen mass fraction determined on a dry basis, \%;

$\mathrm{w}(\mathrm{O})_{\mathrm{d}}$ is the oxygen mass fraction determined on a dry basis, \%;

$\mathrm{w}(\mathrm{N})_{\mathrm{d}}$ is nitrogen mass fraction determined on a dry basis, $\%$.

The ash content was determined according to the requirements of SM EN 18122:2017 by slow calcining the samples in the electric muffle furnace LAC type LH 05/13 production (made in the Czech Republic) at $550{ }^{\circ} \mathrm{C}$ for about $6 \mathrm{~h}$. The samples were prepared in accordance with the requirements of SM EN 14780:2017. The maximum particle size was $1 \mathrm{~mm}$. Ash content was calculated using the following equation:

$$
A=\frac{\left(m_{3}-m_{1}\right)}{\left(m_{2}-m_{1}\right)} \cdot \frac{100}{100-W} \cdot 100
$$

where $m_{1}$ is the mass of the empty crucible, $g ; m_{2}$ is the mass of the crucible plus mass of the test sample, $g ; m_{3}$ is the mass of the crucible plus mass of ash, $g$, and $W$ is the moisture content of the test sample, $\%$.

\section{Results and Discussions}

\subsection{SEM Analysis}

Apricot, peach and plum samples were pre-dried and had variable grain sizes: (a) plum: 650-700 micron large particles; 150-200 micron small particles + fine particles; (b) peach: 900 micron - 1 mm large particles; 250-300 micron small particles + fine particles; (c) apricot: 1-1.1 mm large particles; 250-300 micron small particles + fine particles. The samples were positioned on stab-type holders by using carbon tape.

Because the wood is dielectric, low values of the working voltage were used, correlated with the maximum magnification power of $2000 \times$. Above this value, the image was blurred because of the high contrast. Accordingly, the SEM analysis was performed with the parameters: $\mathrm{HV}: 10 \mathrm{kV}$ (half the value used for a metal sample); low vacuum mode (60 Pa) in the working chamber; working distance to the sample (WD): $15 \mathrm{~mm}$; LFD detector (large field detector), spot size: 5 . 
Figure 2 shows SEM images of the raw material from the three types of samples. There was a fibrous structure with multiple orientations determined by the type and method of detachment of the wood during the processing.

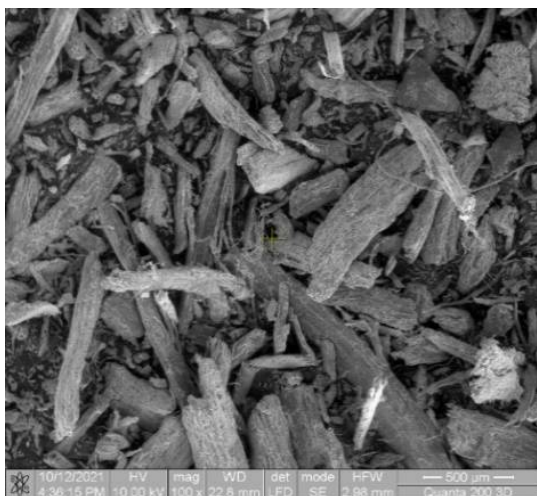

(a)

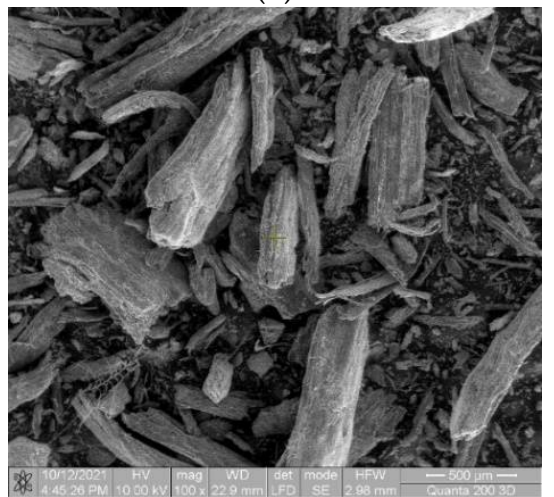

(d)

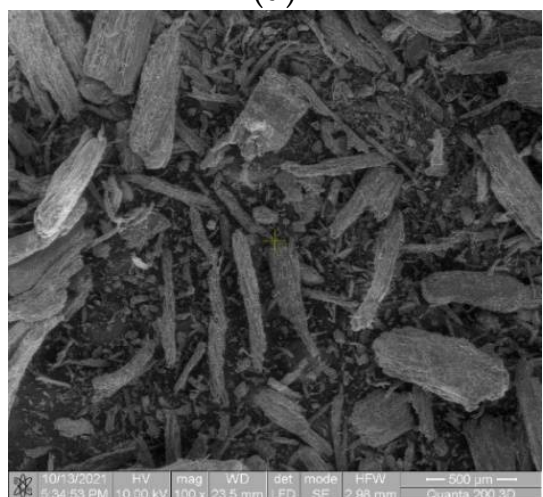

(g)

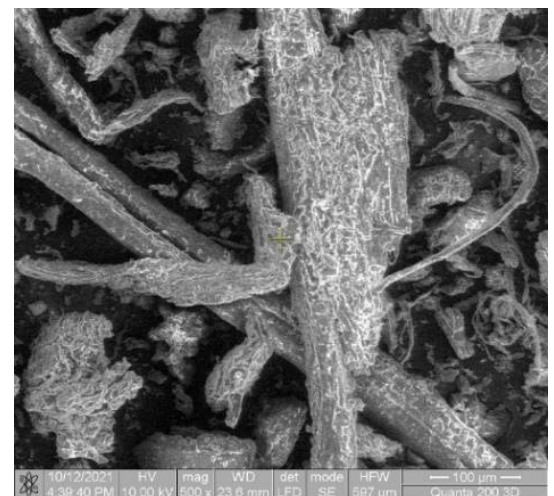

(b)

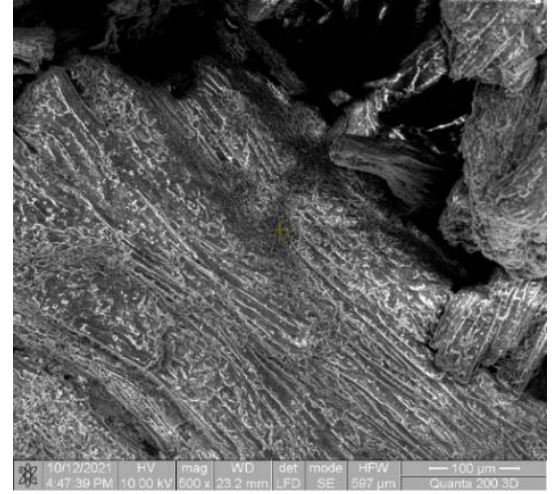

(e)

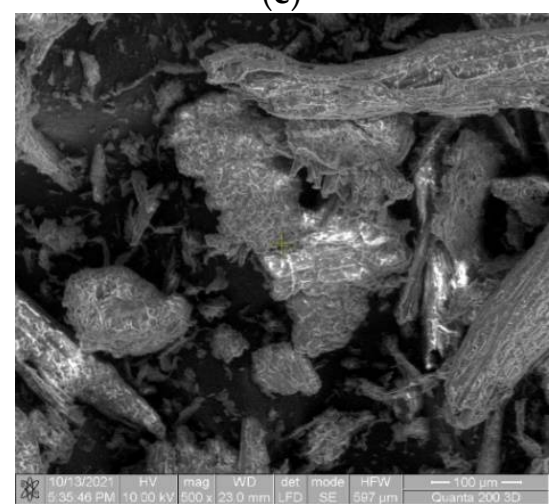

(h)

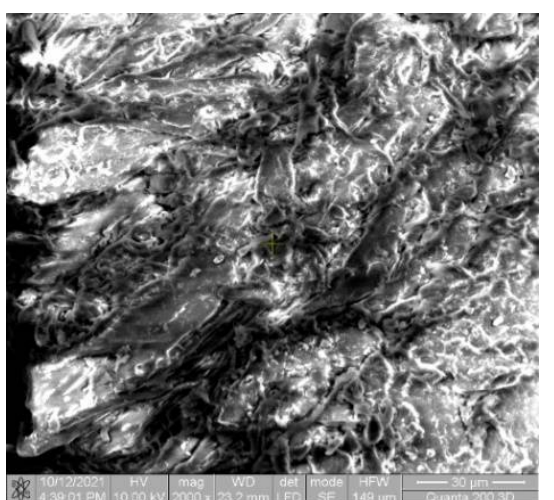

(c)

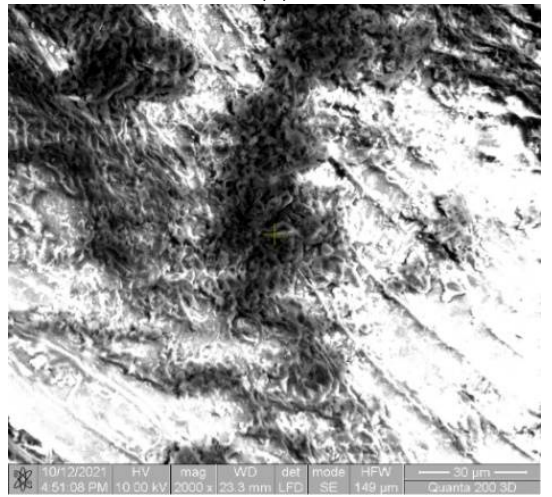

(f)

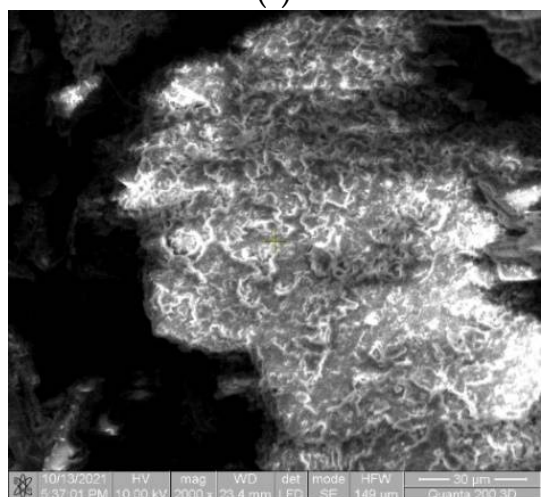

(i)

Figure 2. SEM images of shredded wood biomass at various magnitudes: (a) apricot-100 $\times$; (b) apricot-500×; (c) apricot-2000×; (d) peach-100×; (e) peach-500×; (f) peach-2000×; (g) plum-100×; (h) plum-500×; (i) plum-2000×.

Figure 2 illustrates the microscopic and morphological appearance of the samples. Images were taken at higher magnification values $(2000 \times)$ to observe different types of particles and their size, which were not visible at lower magnification rates. It can be observed that the fibrous structures were directed by the existing micellar structure. The morphology of the shredded raw biomass obtained from fruit trees was partially homogeneous and presented nonuniform macrostructures. In this form, the raw materials can be utilized further to benefit wood processing for lignocelluloses products and their derivatives. This structure exists in the initial form of the trees. Moreover, some cleavage planes on the surface were observed in parts of the particles. Figure $2 c, f, i$, show granular 
structures with variable dimensions between 100 microns and 500 microns and irregular surfaces, respectively. In all three analyzed structures, micropores with different shapes and distributions were highlighted (Figure 2f). Moreover, the SEM images presented an anisotropic form with more pronounced shrinkage observed along the tangential direction (Figure 2e). In Figure 2h, a minimum shrinkage was observed along the longitudinal direction. The detachments of the biomass particles were confirmed and realized within the longitudinal direction of fibers (Figure 2e) and correlated with the results presented by Han et al. [20].

\subsection{XRD Analysis}

Among the chemical components, the wood cell wall, lignin, hemicelluloses and extractives are amorphous, while cellulose is structured in both crystalline and amorphous domains. The ratio between these domains depends on the source and material history, and has a strong influence on the physical and chemical properties of cellulosic materials. The crystallinity of wood is determined by the proportion of crystalline material in the wood; that is, by the content of crystalline cellulose.

XRD is the most common method for determining the crystallinity of partially crystalline materials. XRD patterns of wood are the result of crystalline cellulose reflections super-imposed on a diffuse background. This proves the relationship between the degree of crystallinity and cellulose content of the wood. A quantitative analysis of a multiphase mixture is possible. According to diffracted ray intensity theory, the diffraction intensity of a phase in a multiphase mixture increases as the relative content of the phase increases.

The diffraction patterns of solid-oriented samples from the three different fruit tree wood samples are presented in Figure 3.

The fruit tree species displayed a typical X-ray diffractogram. The reflection of the

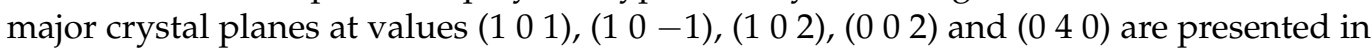
Table 3.

Table 3. The reflection positions of crystal planes and amorphous cellulose forms for the studied wood samples.

\begin{tabular}{|c|c|c|c|c|c|c|c|}
\hline \multirow{2}{*}{ Sample } & \multicolumn{6}{|c|}{ Diffraction Angle 2 $\theta$, Degree } & \multirow{2}{*}{ Cr.I, \% } \\
\hline & $\left(\begin{array}{lll}1 & 0 & 1\end{array}\right)$ & $\left(\begin{array}{lll}1 & 0 & -1\end{array}\right)$ & Am & $\left(\begin{array}{lll}1 & 0 & 2\end{array}\right)$ & $\left(\begin{array}{lll}0 & 0 & 2\end{array}\right)$ & $\left(\begin{array}{llllllllllllll}0 & 4 & 0\end{array}\right)$ & \\
\hline Apricot & 15.08 & 16.50 & 19.94 & 20.52 & 22.62 & 34.98 & 47.42 \\
\hline Peach & 14.89 & 16.42 & 19.64 & 20.38 & 22.27 & 34.61 & 40.15 \\
\hline Plum & 14.87 & 16.49 & 19.54 & 20.16 & 22.20 & 34.83 & 45.28 \\
\hline
\end{tabular}

The diffractograms were deconvoluted using Lorentzian and Gaussian peak functions [37]. After deconvolution, the crystalline index, Cr.I. (\%), was calculated using Equation 6, where $A_{\text {cryst }}$ is the sum of the peak areas (101), (10-1), (002), and (012), and $A_{\text {total }}$ is the total area under the diffractogram [38].

$$
\operatorname{CrI}(\%)=\frac{A_{\text {cryst }}}{A_{\text {total }}} 100
$$

The crystalline index of the fruit tree biomass samples ranged from $40.15 \%$ to $47.42 \%$ and correlated with cellulose content (Table 4). 


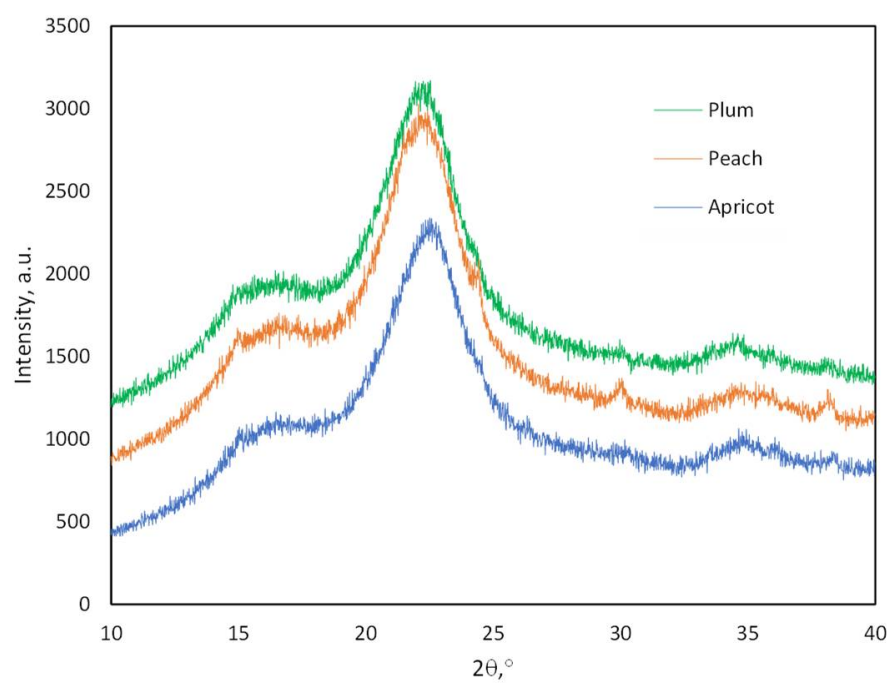

(a)

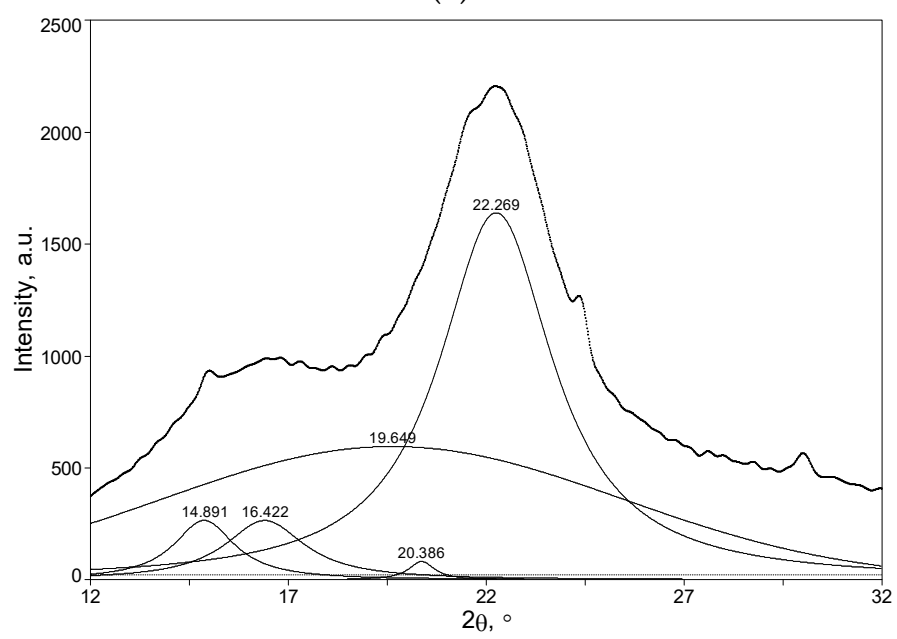

(c)

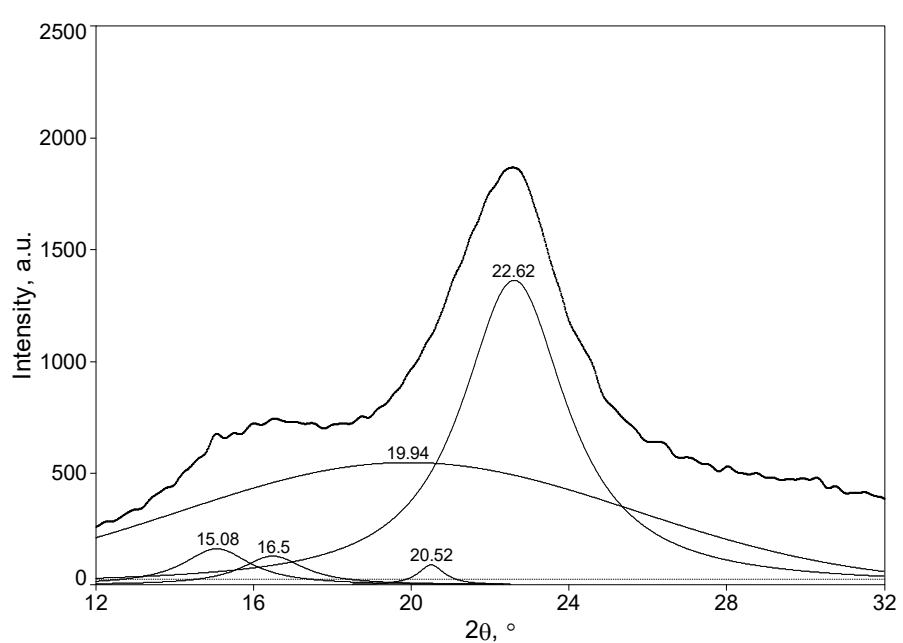

(b)

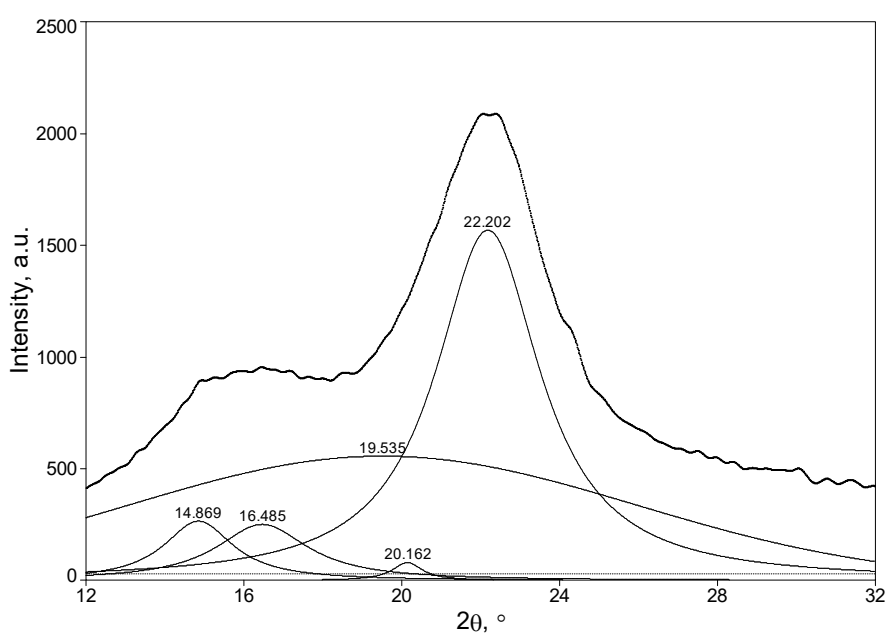

(d)

Figure 3. Unprocessed (a) and deconvoluted X-ray diffractograms of: (b) apricot, (c) peach, and (d) plum tree wood samples.

Table 4. Contents of structural components.

\begin{tabular}{ccccc}
\hline Sample & $\begin{array}{c}\text { Extractives } \\
\text { Alc.-Toluene, } \%\end{array}$ & Lignin, \% & Cellulose, \% & Hemicelluloses, \% \\
\hline Apricot & 20.01 & 22.77 & 33.19 & 24.04 \\
\hline Peach & 24.22 & 23.28 & 28.68 & 23.82 \\
\hline Plum & 22.80 & 23.25 & 32.96 & 20.99 \\
\hline
\end{tabular}

\subsection{FT-IR Analysis}

FT-IR spectroscopy is a very useful technique for analyzing the structure of wood chemical components. FT-IR spectra recorded for different wood species are shown in Figure 4. 


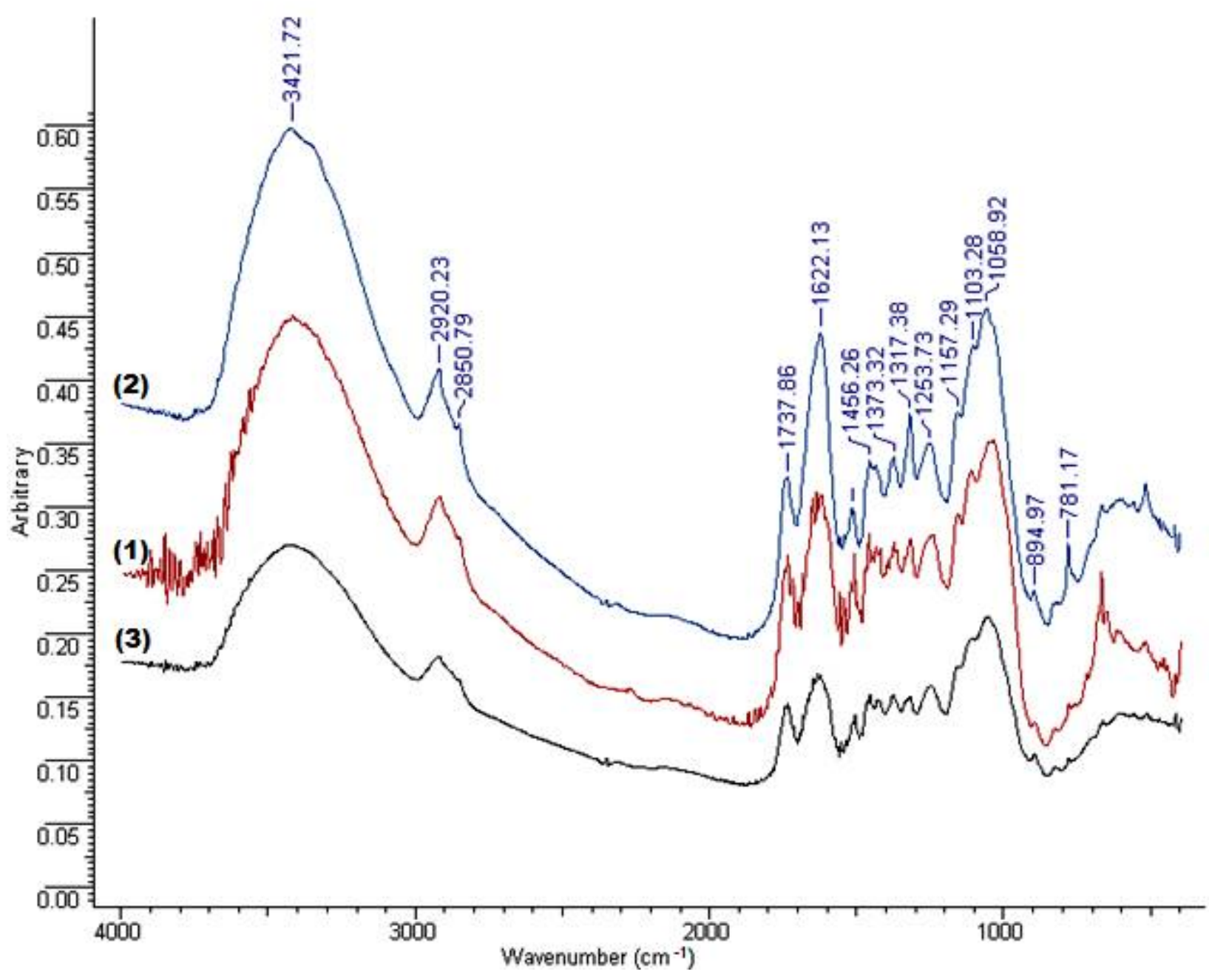

Figure 4. FTIR spectra: (1) plum, (2) apricot, and (3) peach.

In the $3800-2700 \mathrm{~cm}^{-1}$ region (Figure 4), strong hydrogen bonded $(\mathrm{O}-\mathrm{H})$ stretching absorptions and prominent $\mathrm{C}-\mathrm{H}$ stretching absorptions were observed. It can be observed that all bands in this region had different intensities in the spectra of wood samples.

The spectra of wood samples were very complex in the "fingerprint" region. Here, we found bands assigned to different stretching vibrations of the groups from the main wood components. The bands at 1595,1510 , and $1270 \mathrm{~cm}^{-1}$ were assigned to $C=C$ and $\mathrm{C}-\mathrm{O}$ stretching or bending vibrations of different groups from lignin. The bands at 1460, $1425,1335,1220$, and $1110 \mathrm{~cm}^{-1}$ were assigned to characteristic $\mathrm{C}-\mathrm{H}$ and $\mathrm{C}-\mathrm{O}$ deformation, bending or stretching vibrations of different groups for lignin and carbohydrates. The bands at $1735,1375,1240,1165,1060,1030 \mathrm{~cm}^{-1}$ are assigned to characteristic $\mathrm{C}=\mathrm{O}, \mathrm{C}-\mathrm{H}$, $\mathrm{C}-\mathrm{O}-\mathrm{C}, \mathrm{C}-\mathrm{O}$ deformation or stretching vibrations of different groups from carbohydrates. However, in the different types of wood, the positions and relative intensity of the bands were different $[39,40]$.

The relation between lignin and carbohydrates can be calculated by the ratio of some bands of the FT-IR spectra. As was expected, the lignin/carbohydrate ratio was different for all wood samples, as was evident from the increase in the $1505 \mathrm{~cm}^{-1}$ band assigned to lignin and the decrease in the $1738 \mathrm{~cm}^{-1}$ band assigned to carbohydrates. The $1505 \mathrm{~cm}^{-1}$ band was used as an internal standard assigned to benzene ring stretching vibration for lignin. 


\subsection{Calorific Results, Ash Content, and Moisture at Harvest}

According to the obtained experimental results (Table 5), the pruning-derived biomass from apricot, peach and plum trees had a net caloric value at 10\% humidity, varying between $17,406 \mathrm{~J} / \mathrm{g}$ (for apricot) and 17,828 J/g (for plum). Thus, at this qualitative indicator, the studied biomass could certainly be used in the production of densified solid biofuels in the form of pellets and briquettes. The ash content also met the requirements of ENPlus3. Results were obtained for five similar measurements, with standard errors calculated as percentages of the maximum and minimum values reported to the calculated mean values.

Table 5. Calorific results, ash content, and moisture at harvest.

\begin{tabular}{|c|c|c|c|c|c|c|}
\hline Sample & Parameters & $\underset{\mathrm{J} / \mathrm{g}}{\mathrm{q}_{\mathrm{v}, \mathrm{gr}, \mathrm{d}}}$ & $\mathbf{q}_{\mathrm{p}, \text { net, } \mathrm{d}}$ & 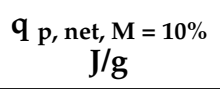 & $\begin{array}{l}\mathrm{A} \\
\%\end{array}$ & $\begin{array}{c}\mathbf{M}_{\mathrm{ar}} \\
\%\end{array}$ \\
\hline \multirow[b]{2}{*}{ Apricot } & Mean value & $20,925.9$ & $19,612.2$ & $17,406.7$ & $0.88 \%$ & $24.31 \%$ \\
\hline & Confidence limits & $\begin{array}{l}+0.26 \% \\
-0.65 \%\end{array}$ & $\begin{array}{l}+0.28 \% \\
-0.70 \%\end{array}$ & $\begin{array}{l}+0.29 \% \\
-0.71 \%\end{array}$ & $\begin{array}{l}+3.40 \% \\
-2.27 \%\end{array}$ & $\begin{array}{l}+0.39 \% \\
-0.63 \%\end{array}$ \\
\hline \multirow[b]{2}{*}{ Peach } & Mean value & $21,359.9$ & $20,041.4$ & $17,793.0$ & $1.30 \%$ & $23.41 \%$ \\
\hline & Confidence limits & $\begin{array}{l}+0.07 \% \\
-0.08 \%\end{array}$ & $\begin{array}{l}+0.03 \% \\
-0.10 \%\end{array}$ & $\begin{array}{l}+0.03 \% \\
-0.10 \%\end{array}$ & $\pm 1.54 \%$ & $\begin{array}{l}+0.25 \% \\
-0.42 \%\end{array}$ \\
\hline \multirow[b]{2}{*}{ Plum } & Mean value & $21,397.6 \%$ & $20,081.3 \%$ & $17,828.8 \%$ & $0.8 \%$ & $33.2 \%$ \\
\hline & Confidence limits & $\pm 0.01 \%$ & $\begin{array}{l}+0.03 \% \\
-0.07 \%\end{array}$ & $\begin{array}{l}+0.03 \% \\
-0.07 \%\end{array}$ & $\pm 7.0 \%$ & $\begin{array}{l}+2.86 \% \\
-3.63 \%\end{array}$ \\
\hline
\end{tabular}

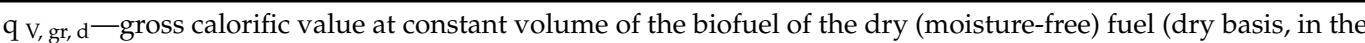
dry matter), J/g; q v, gr, - net calorific value at constant pressure of the dry (moisture-free) fuel, J/g; q v, gr, net calorific value at constant pressure of the biofuel with moisture content $\mathrm{M}=10 \%, \mathrm{~J} / \mathrm{g}$; $\mathrm{A}$-ash content, $\%$ Mar-moisture content at harvest, \%.

\subsection{Comparison of Lignin, Cellulose, and Hemicelluloses Contents}

The net calorific value of solid biofuels depends on the chemical composition of the wood waste used for this purpose. The main chemical components of wood, lignin and extractives have a major influence on the caloric value [29-31]. Table 4 presents the extractable matter content, lignin, cellulose and hemicelluloses percentages. The values are expressed as \% based on dry weight and statistical significance was analyzed by least significant difference (LSD) $(p<0.05)$. Extractive content ranged from $20.01 \%$ (apricot) to $24.22 \%$ (peach), lignin content ranged from $22.77 \%$ (apricot) to $23.28 \%$ (peach), cellulose content varied from $28.68 \%$ (peach) to $33.19 \%$ (apricot), and hemicelluloses content ranged from $20.99 \%$ (plum) to $24.04 \%$ (apricot).

The chemical composition of the wood waste varied from species to species, but also according to the percentage of bark found in the wood waste. Thus, if the percentage of bark in the waste was high, then considerably higher values for extractives and lignin were be recorded. This is due to the fact that bark contains much lower amounts of polysaccharides in relation to the mass of the central cylinder.

\section{Conclusions}

According to the obtained results on morphological structure and the properties of three fruit trees (apricots, peaches, and plums) widely grown in the region of the Prut River, the cellulose content of the biomass samples correlated with the crystallinity index determined by X-ray diffraction. However, attention must be paid in future studies to the bark content of the biomass samples, which may alter the mentioned correlation.

Regarding the analysis of constituent components of the biomass samples, it can be concluded that the higher contents of lignin or extractive substances were reflected in higher calorific values. Plum appeared to be the best solid biomass resource based on its calorific output, lignin content, and ash content, but close results were also obtained for peach and apricot trees. 
Based on the findings, it can be concluded that wood residues, generated from the pruning of apricot, peach, and plum trees, present a reliable source of raw material for the production of densified solid biofuels with quality characteristics complying with the requirements of ENPlus 3 standards.

The quality of densified solid biofuels (pellets) is affected by two major factors: (1) the chemical composition and physical properties of raw materials, and (2) the technological parameters of the densification/pelletization process, which determine the physical and mechanical properties of the pellets. A qualified energy product requires a combination of these two factors. The obtained results suggest that future research may lead to the development of biomass blends that can produce solid biofuels not only with desired calorific value, but also with other desirable characteristics (bulk density, ash content, burning rate, etc.).

Author Contributions: Conceptualization, G.M., G.I. and C.M.; methodology, F.C., B.N., A.G. and C.M.; software, F.C., N.D. and B.I.; validation, B.I., B.N., A.G. and V.P.; formal analysis, N.D.; investigation, B.I., B.N., A.G., F.C., N.D. and V.P.; resources, G.M., G.I. and C.M.; data curation, B.I, N.D., A.G. and B.N.; writing-original draft preparation, V.P., F.C. and B.I.; writing-review and editing, V.P., F.C. and B.I.; visualization, N.D., V.P., B.N. and A.G.; supervision, G.M., G.I. and C.M.; project administration, G.M. and G.I.; funding acquisition, G.I., G.M. and C.M. All authors have read and agreed to the published version of the manuscript.

Funding: This research was funded by the Joint Operational Programme Romania-Republic of Moldova 2014-2020, grant number 2Soft/1.2/44 BCS Ro-Md cross-border grant project "Improving the quality of solid biofuels produced from raw material collected from both sides of Prut river", financed by ENI CBC.

Acknowledgments: The authors are grateful to the Joint Operational Programme Romania-Republic of Moldova 2014-2020, grant number 2Soft/1.2/44 BCS Ro-Md cross-border grant project "Improving the quality of solid biofuels produced from raw material collected from both sides of Prut river" and the financial support of ENI CBC Agency.

Conflicts of Interest: The authors declare no conflict of interest. The funders had no role in the design of the study; in the collection, analyses, or interpretation of data; in the writing of the manuscript, or in the decision to publish the results.

\section{References}

1. Malico, I.; Nepomuceno Pereira, R.; Gonçalves, A.C.; Sousa, A.M.O. Current status and future perspectives for energy production from solid biomass in the European industry. Renew. Sustain. Energy Rev. 2019, 112, 960-977. [CrossRef]

2. Sikkema, R.; Proskurina, S.; Banja, M.; Vakkilainen, E. How can solid biomass contribute to the EU's renewable energy targets in 2020, 2030 and what are the GHG drivers and safeguards in energy- and forestry sectors? Renew. Energy. 2021, 165, 758-772. [CrossRef]

3. Biljuš, H.; Basarac Sertić, M. Potential and Role of Biomass in Croatian and European Energy Transition. Drv. Ind. 2021, 72, 309-318. [CrossRef]

4. Mediavilla, I.; Fernández, M.J.; Barro, R.; Borjabad, E.; Bados, R.; Esteban, L.S. Effect of mechanical harvesting on the chemical composition and combustion behaviour of shrub biomass. Energy 2020, 204, 117928. [CrossRef]

5. Mousa, E.; Wang, C.; Riesbeck, J.; Larsson, M. Biomass applications in iron and steel industry: An overview of challenges and opportunities. Renew. Sustain. Energy Rev. 2016, 65, 1247-1266. [CrossRef]

6. Procházka, P.; Honig, V.; Bouček, J.; Hájková, K.; Trakal, L.; Soukupová, J.; Roubík, H. Availability and Applicability of Wood and Crop Residues for the Production of Wood Composites. Forests 2021, 12, 641. [CrossRef]

7. Ivanova, T.; Mendoza Hernández, A.; Bradna, J.; Fernández Cusimamani, E.; García Montoya, J.; Armas Espinel, D. Assessment of Guava (Psidium Guajava L.) Wood Biomass for Briquettes' Production. Forests 2018, 9, 613. [CrossRef]

8. Kamperidou, V.; Lykidis, C.; Barmpoutis, P. Thermal characteristics of wood of some common native species. In Proceedings of the 27th International Conference on Wood Modification and Technology, Zagreb, Croatia, 13 October 2016.

9. Ngangyo-Heya, M.; Foroughbahchk-Pournavab, R.; Carrillo-Parra, A.; Rutiaga-Quiñones, J.G.; Zelinski, V.; Pintor-Ibarra, L.F. Calorific Value and Chemical Composition of Five Semi-Arid Mexican Tree Species. Forests 2016, 7, 58. [CrossRef]

10. Thiffault, E.; Barrette, J.; Blanchet, P.; Nguyen, Q.N.; Adjalle, K. Optimizing Quality of Wood Pellets Made of Hardwood Processing Residues. Forests 2019, 10, 607. [CrossRef] 
11. Reis Portilho, G.; Resende de Castro, V.; de Cássia Oliveira Carneiro, A.; Cola Zanuncio, J.; José Vinha Zanuncio, A.; Gabriella Surdi, P.; Gominho, J.; de Oliveira Araújo, S. Potential of Briquette Produced with Torrefied Agroforestry Biomass to Generate Energy. Forests 2020, 11, 1272. [CrossRef]

12. Gruber, L.; Seidl, L.; Zanetti, M.; Schnabel, T. Calorific Value and Ash Content of Extracted Birch Bark. Forests 2021, $12,1480$. [CrossRef]

13. Wu, M.R.; Schott, D.L.; Lodewijks, G. Physical properties of solid biomass. Biomass Bioenergy 2011, 35, 2093-2105. [CrossRef]

14. Trubetskaya, A.; Jensen, P.A.; Jensen, A.D.; Garcia Llamas, A.D.; Umeki, K.; Glarborg, P. Effect of fast pyrolysis conditions on biomass solid residues at high temperatures. Fuel Processing Technol. 2016, 143, 118-129. [CrossRef]

15. Wang, X.; Li, H.; Cao, Y.; Tang, Q. Cellulose Extraction from Wood Chip in an Ionic Liquid 1-Allyl-3-Methylimidazolium Chloride (AmimCl). Bioresour. Technol. 2011, 102, 7959-7965. [CrossRef]

16. Cardoso, G.V.; Di Salvo Mello, L.R.; Zanatta, P.; Cava, S.; Raubach, C.W.; Moreira, M.L. Physico-Chemical Description of Titanium Dioxide-Cellulose Nanocomposite Formation by Microwave Radiation with High Thermal Stability. Cellulose 2018, 25, $2331-2341$. [CrossRef]

17. Moon, R.J.; Martini, A.; Nairn, J.; Simonsen, J.; Youngblood, J. Cellulose nanomaterials review: Structure, properties and nanocomposites. Chem. Soc. Rev. 2011, 40, 3941-3994. [CrossRef]

18. Choi, K.; Gao, C.Y.; Nam, J.D.; Choi, H.J. Cellulose-Based Smart Fluids under Applied Electric Fields. Materials 2017, 10, 1060. [CrossRef]

19. Park, D.P.; Hwang, J.Y.; Choi, H.J.; Kim, C.A.; Jhon, M.S. Synthesis and characterization of polysaccharide phosphates based electrorheological fluids. Mater. Res. Innov. 2003, 7, 161-166. [CrossRef]

20. Han, X.; Ye, Y.; Lam, F.; Pu, J.; Jiang, F. Hydrogen-Bonding-Induced Assembly of Aligned Cellulose Nanofibres into Ultrastrong and Tough Bulk Materials. J. Mater. Chem. A 2019, 7, 27023-27031. [CrossRef]

21. Song, J.; Chen, C.; Zhu, S.; Zhu, M.; Dai, J.; Ray, U.; Li, Y.; Kuang, Y.; Li, Y.; Quispe, N.; et al. Processing Bulk Natural Wood into a High-Performance Structural Material. Nature 2018, 554, 224-228. [CrossRef]

22. Magalhães, D.; Gürel, K.; Matsakas, L.; Christakopoulos, P.; Pisano, I.; Leahy, J.J.; Kazanç, F.; Trubetskaya, A. Prediction of Yields and Composition of Char from Fast Pyrolysis of Commercial Lignocellulosic Materials, Organosolv Fractionated and Torrefied Olive Stones. Fuel 2021, 289, 119862. [CrossRef]

23. Pizzi, A.; Properzi, M.; Leban, J.-M.; Zanetti, M.; Pichelin, F. Mechanically-induced wood welding. Maderas Cienc. Tecnol. 2003, 5 , 101-106. [CrossRef]

24. Zikeli, F.; Vinciguerra, V.; Taddei, A.R.; D'Annibale, A.; Romagnoli, M.; Scarascia Mugnozza, G. Isolation and Characterization of Lignin from Beech Wood and Chestnut Sawdust for the Preparation of Lignin Nanoparticles (LNPs) from Wood Industry Side-Streams. Holzforschung 2018, 72, 961-972. [CrossRef]

25. Ianus,, G.; Munteanu, C.; Măluțan, T.; Marian, G.; Ciolacu, F.; Paleu, V.; Istrate, B. Morphological and microstructural aspects of some specific vegetal biomass and their structural components. In The 21th International Scientific Conference "Tehnomus", "Ştefan cel Mare", University of Suceava, Romania, 11-13 November 2021; Tehnomus Journal "New Technologies and Products in Machine Manufacturing Technologies": Suceava, România, 2021.

26. Xu, E.; Wang, D.; Lin, L. Chemical Structure and Mechanical Properties of Wood Cell Walls Treated with Acid and Alkali Solution. Forests 2020, 11, 87. [CrossRef]

27. Fahlén, J. The Cell Wall Ultrastructure of Wood Fibres: Effects of the Chemical Pulp Fibre Line. Ph.D. Thesis, KTH, Stockholm, Sweden, 2005. Available online: http:// urn.kb.se/resolve?urn=urn:nbn:se:kth:diva-129 (accessed on 4 January 2022).

28. Merela, M.; Thaler, N.; Balzano, A.; Plavčak, D. Optimal Surface Preparation for Wood Anatomy Research of Invasive Species by Scanning Electron Microscopy. Drv. Ind. 2020, 71, 117-127. [CrossRef]

29. Pavlenco, A.; Marian, G.; Gudîma, A. Calitatea potențialul energetic al reziduurilor agricole: Studiu de caz pentru Regiunea de Dezvoltare Nord, Republica Moldova. Stiința Agric. 2018, 2, 141-148.

30. Marian, G.; Ianus, G.; Istrati, B.; Gudîma, A.; Nazar, B.; Pavlenco, A.; Daraduda, N. Quality of pellets produced from agricultural wood residues specific to the Prut river basin. Вісник Аграрної Науки Причорномор'я 2021, 1, 84-93. [CrossRef]

31. Gudîma, A. Evaluarea utilizării reziduurilor agricole pentru scopuri energetice. Studiu de caz pentru raionul Soroca, Republica Moldova. Meridian Ing. 2017, 1, 26-29.

32. Nosek, R.; Holubcik, M.; Jandacka, J. The impact of bark content of wood biomass on biofuel properties. BioResources 2016, 11, 44-53. [CrossRef]

33. Alakangas, E. Biomass and agricultural residues for energy generation. In Fuel Flexible Energy Generation; Oakey, J., Ed.; Woodhead Publishing: Elsevier, NY, USA, 2016; pp. 59-96. ISBN 9781782423782. [CrossRef]

34. Pavlenco, A. Calitatea biocombustibilior solizi produși din reziduuri agricole. Articol de sinteză. Stiința Agric. 2018, 2, 128-140.

35. Vassilev, S.V.; Baxter, D.; Andersen, L.K.; Vassileva, C.G. An overview of the chemical composition of biomass. Fuel 2010, 89, 913-933. [CrossRef]

36. Gao, X.; Kumar, R.; Wyman, C.E. Fast hemicellulose quantification via a simple one-step acid hydrolysis. Biotechnol. Bioeng. 2014, 111, 1088-1096. [CrossRef] [PubMed]

37. Ciolacu, D.; Ciolacu, F.; Popa, V.I. Amorphous cellulose-structure and characterization. Cellul. Chem. Technol. 2011, 45, 13.

38. Hermans, P.H.; Weidinger, A. On the diffusely diffracted radiation in the X-ray diagrams of cellulose fibres. Rec. Trav. Chim. Pays Bas. 2010, 65, 620-623. [CrossRef] 
39. Kondo, T. Hydrogen bonds in cellulose and cellulose derivatives. In Polysaccharides II-Structural Diversity and Functional Versatility; Dumitriu, S., Ed.; Marcel Dekker: New York, NY, USA, 2005; pp. 69-98.

40. Nishiyama, Y.; Sugiyama, J.; Chanzy, H.; Langan, P. Crystal Structure and Hydrogen Bonding System in Cellulose I $\alpha$ from Synchrotron X-ray and Neutron Fiber Diffraction. J. Am. Chem. Soc. 2003, 125, 14300-14306. [CrossRef] [PubMed] 